\title{
Optimum Management of Leaf Removal and Lateral Branch Fruit Set in Winter-Planted Cultivation of Paprika
}

\author{
Dong-Cheol Jang ${ }^{1,+}+\mathbb{D}$, Seong-Ho Yang ${ }^{1,+}{ }^{+}$, Won-Ho $\mathrm{Na}^{2}$, Min-Hyeok Jeong ${ }^{1}$, Hwi-Chan Yang ${ }^{1}$, Young-Ho Kim ${ }^{1}$, \\ Eun-Hye Hong ${ }^{1}$, Ki-Young Choi ${ }^{3}$, Il-Seop Kim ${ }^{1,2, *}$ and Ngoc-Thang Vu ${ }^{4, *}$ \\ 1 Department of Horticulture, Kangwon National University, Chuncheon 24341, Korea; \\ jdc@kangwon.ac.kr (D.-C.J.); gleldgh@naver.com (S.-H.Y.); wjdalsgur970@naver.com (M.-H.J.); \\ jack955@naver.com (H.-C.Y.); rladydgh99@naver.com (Y.-H.K.); aiqht7@kangwon.ac.kr (E.-H.H.) \\ 2 Department of Interdisciplinary Program in Smart Agriculture, Kangwon National University, \\ Chuncheon 24341, Korea; rwi954@naver.com \\ 3 Department of Agriculture and Industries, Kangwon National University Graduate School, \\ Chuncheon 24341, Korea; choiky@kangwon.ac.kr \\ 4 Faculty of Agronomy, Vietnam National University of Agriculture, Hanoi 131000, Vietnam \\ * Correspondence: kimilsop@kangwon.ac.kr (I.-S.K.); vungocthang@vnua.edu.vn (N.-T.V.) \\ + These authors contributed equally to this work.
}

\section{check for} updates

Citation: Jang, D.-C.; Yang, S.-H.; Na, W.-H.; Jeong, M.-H.; Yang, H.-C.; Kim, Y.-H.; Hong, E.-H.; Choi, K.-Y.; Kim, I.-S.; Vu, N.-T. Optimum

Management of Leaf Removal and

Lateral Branch Fruit Set in Winter-Planted Cultivation of Paprika. Horticulturae 2021, 7, 348. https://doi.org/10.3390/

horticulturae7100348

Academic Editor: Stefania De Pascale

Received: 28 July 2021

Accepted: 24 September 2021

Published: 29 September 2021

Publisher's Note: MDPI stays neutral with regard to jurisdictional claims in published maps and institutional affiliations.

Copyright: (c) 2021 by the authors. Licensee MDPI, Basel, Switzerland. This article is an open access article distributed under the terms and conditions of the Creative Commons Attribution (CC BY) license (https:/ / creativecommons.org/licenses/by/ $4.0 /)$.

\begin{abstract}
This study was carried out to balance the production and consumption of assimilates according to crop conditions as a basis to reduce the waste of assimilation through leaf and fruit control. There were four treatments: one fruit and two leaves (F1L2); two fruits and two leaves (F2L2); two fruits and three leaves (F2L3); and two fruits and four leaves (F2L4). This study showed that, as the number of leaves increased in Periods 1 and 2, the stem diameter and average weight decreased, with F1L2 having the highest stem diameter and average weight, although its numbers of leaves and fruits were the fewest. In the summer, Period 3, F1L2 production was the lowest due to increased rates of flower drop and fruit drop. In Period 4, when ambient temperature and light levels were decreased, the number of fruits was increased. However, the production was decreased. F1L2 and F2L4 showed significant decreases in production. Although F1L2 showed the highest average weight, it had a low production due to a decrease in the number of fruits. F2L4 showed weak generative growth due to an imbalance in growth over the summer. After reaching the last stage of development, the number of leaves showed the highest average weight and production in F2L4.
\end{abstract}

Keywords: Capsicum annuum L.; fruit load; LAI; summer crop; sink-source

\section{Introduction}

Cultivation types of paprika can be divided into winter and summer cropping season according to latitude and altitude. In the winter cropping season, sowing is performed in July and August and the harvest time is from November to June or July of the following year. In the summer cropping season, sowing is from January to March and the harvest is from November to December. Although the cultivation area during the summer cropping season mainly centered on highlands in South Korea, it was increased rapidly from 17 hectares in 2003 to 100 hectares in 2015 and the crop yield per unit area of paprika in Gangwon province was $8.69 \mathrm{t} / 10 \mathrm{a}$, which was only $67.9 \%$ and $82.9 \%$ of that in Jeolla province $(12.797 \mathrm{t} / 10 \mathrm{a})$ and Gyeongsang province $(10.481 \mathrm{t} / 10 \mathrm{a})$, respectively. Paprika yield was approximately 80,000 tons from 730 hectares, of which 31,919 tons (39.9\%) were exported. The main export destinations were Japan (99.5\%), Taiwan (0.3\%), and Hong Kong (0.2\%). From March to July (2709 to 4528 tons/month), an oversupply period, the yield exceeded the average annual export volume. However, from August to October and from January to February (1192 to 1780 tons/month), the yield was only $44-65 \%$ of the average. The short supply period occurred due to the suspension period of summer cropping and winter cropping 
seasons. Especially from August to October, the growth balance collapsed due to the high temperature and humid environment caused by the rainy season. Such a short supply period emerged as a major problem for the export of stable agricultural products. To overcome this problem, developing a cultivation technology that can overcome the high temperature of the summer cropping season in the highlands, the main production area during that period, is required.

However, the cultivation technology has not been established yet, resulting in low yield and quality. This is due to the application of working standards that do not consider the condition of the crop, as well as environmental factors such as the rainy season and the hot season.

Sink-source adjustment is indispensable for maintaining the balance of crops. The method of adjusting the sink-source in paprika cultivation is by adjusting the LAI (Leaf Area Index) [1-5] and the fruit setting number [6,7]. Because leaf area and thickness have a great influence on the photosynthesis rate, it is paramount to maintain a leaf area suitable for growth balance $[4,5]$. An excessive increase in LAI will cause a high respiratory volume and the lack of required light due to shading, resulting in reduced net photosynthesis $[8,9]$. Hence, proper defoliation is crucial. Although defoliation reduces the total leaf area of crops, it increases nutrient absorption and the yield and movement of photosynthesis products [2,3] since the dry mass yield is proportional to the light requirement of the colony [10]. Therefore, adjusting the leaf area depending on the number and size of lateral branches is important. Even if the leaf area is the same, the proportion of fallen flowers and fallen fruits may vary, which is closely related to the sink strength rate of fruits previously set [11].

For this reason, it is essential to maintain LAI and fruit load by establishing standards for defoliation and removing fruits suitable for the environment of the cultivation area for high productivity. However, most studies conducted to date and accompanying cultivation standards were conducted in the winter cropping season. Only a few studies were conducted in the summer cropping season. In particular, there are no standards that can be used by farms that have adopted the method of sowing in October and planting in December, which is being attempted as a new summer cropping season. Therefore, the objective of this study was to determine characteristics of the growth and quantity of farms that adopted the method of advancing the planting season by planting in winter and harvesting in summer (which is increasing in the highlands of South Korea). Findings of this study could be used as basic data and a standard for proper management of leaf thinning and fruit setting according to the external environment and crop conditions.

\section{Materials and Methods}

This experiment was conducted from 24 January to 31 December in a plastic film greenhouse $(80 \times 8 \times 5 \mathrm{~m})$ located in Inje, Gangwon province, Korea. The variety used was Redwing RZ (Rijk Zwaan, De Lier, The Netherlands), a red paprika, which was sown on December 4.

Treatment plots were arranged in four ways depending on flower thinning and defoliation, leaving one flower and one leaf of the lateral branch in all experimental plots. When the first flower bloomed on the second node at 10-day intervals from 23 March, the following four methods were performed: (1) treatment by removing all flowers from the lateral branch and leaving one leaf (F1L2), (2) treatment by leaving one flower and one leaf on the lateral branch (F2L2), (3) treatment by leaving one flower and two leaves on the lateral branch, and (4) treatment by leaving one flower and three leaves (F2L4). Among these treatment plots, F2L4 treatment had the largest number of leaves in the crop plant, followed by F2L3 and F2L2.

These experimental plots were planted in rock wool (Expert Grodan, Co., Roermond, $120 \times 12 \times 7.5 \mathrm{~cm}$ ) on 24 January, at a planting density of 6.8 stems per $\mathrm{m}^{2}$. Three stems of experimental plots were cultivated. 
Planted crops were managed so that the average temperature for $24 \mathrm{~h}$ was maintained at $20-22{ }^{\circ} \mathrm{C}$ using a complex environmental control system (CONNEXT 906 Version, Priva B.V, The Netherlands). Liquefied carbonic acid (Sundo Chemical, Korea) was used as a fertilizer to maintain the concentration of carbon dioxide in the greenhouse at 400-700 ppm. The culture solution was supplied over the entire growing period using a Dutch PBG (proefstion voor bloemisterij en glasgroenpe) nutrient solution (non-circulating). EC was supplied between $2.1-2.8 \mathrm{dS} \cdot \mathrm{m}^{-1}$. In addition, the daily supply was adjusted to maintain EC in the range of $3.5-5.0 \mathrm{dS} \cdot \mathrm{m}^{-1}$ and moisture content at $55-65 \%$. Pests were controlled by the IPM (integrated pest management) method using natural enemies and eco-friendly pesticides. The growth survey was conducted as follows. The total growth period over 40 weeks was divided into 8 weeks for a total of five sections (Period 1: 13th-20th week; Period 2: 21st-28th week; Period 3: 29th-36th week; Period 4: 37th-44th week; and Period 5: 45th-52nd week). Plant height, flowering position, stem diameter, leaf length, leaf width, leaf area index, number of nodes, node generation rate, internode length, fruit setting number, number of harvested fruits, and the average number of leaves were surveyed weekly.

Plant height was measured based on the length from the lower part to the growing point. Flowering position was measured based on the length from the growing point to the fully bloomed flower. Leaf length and leaf width were measured based on the leaf of the node that determined the location of flowering. Stem diameter was measured based on the height of the 1-week-ago growing point. Fruit setting was measured based on a fruit length of more than $1 \mathrm{~cm}$. Harvested fruits were measured based on normally harvested fruits that were colored more than $90 \%$ Leaf area index (LAI) was determined using the following non-destructive survey formula. It can be investigated following the change in growth. Plant height increase, node increase, and harvested fruit rate were calculated using the following formulas:

Leaf area index $($ LAI $)=$ Leaf length $(\mathrm{cm}) \times$ Leaf width $(\mathrm{cm}) \times 0.6 \times S D \times\left\{L_{1}+\left(L_{2} \times 0.7\right)\right\}$

$S D$ : Stem density $\left(\mathrm{stem} / \mathrm{m}^{2}\right)$;

$L_{1}$ : Number of leaves on the main stem; $L_{2}:$ Number of leaves on the lateral stem

$$
\begin{gathered}
\text { Plant growth speed }\left(\mathrm{cm} / \text { week) }=\mathrm{PH}_{2}-\mathrm{PH}_{1}\right. \\
\mathrm{PH}_{2} \text { : Plant height this week; } \mathrm{PH}_{1}: \text { Plant height last week; } \\
\text { Node growth speed (node/week) }=\mathrm{N}_{2}-\mathrm{N}_{1} \\
\mathrm{~N}_{2} \text { : Number of nodes this week; } \mathrm{N}_{1}: \text { Number of nodes last week } \\
\text { Ratio of harvested fruit }(\%)=\frac{\text { Number of harvested fruit }}{\text { Number of fruit sets }}
\end{gathered}
$$

Experimental plots were arranged according to a randomized complete block design with three replicates (216 stems per replicate, a total of 648 stems). Quantitative values measured in this experiment are expressed as mean and standard error using the SPSS version 22 (IBM, New York, USA) program. The significance of each experimental plot was tested at the 5\% level using Duncan's multiple range test for each growing season.

\section{Results and Discussion}

Table 1 shows results of investigating the growth and fruit setting characteristics of paprika for each growing period after planting. F1L2 and F2L2 had different fruit setting numbers. However, F1L2 showed high values for all indicators such as growth length, flowering position, and stem diameter. Thus, when the number of leaves was the same, the smaller the fruit setting number, the more the vegetative organs tended to develop. This was consistent with previous results showing that the stem contributed to vegetative growth when the demand for assimilates in sink organs was low [10]. In particular, in Periods 1, 3, and 5, F1L2 was more developed than F2L2. However, in Periods 2 and 3 , the flowering position and stem diameter values were higher than the growth length, indicating the characteristics of vegetative growth. This was considered to be because as 
DIF (the difference between day temperature and night temperature) deviation became larger, length growth developed more as the outside temperature rose sharply after sunrise. The larger the fruit setting number, the more are affected by big DIF.

Table 1. Effect of side leaves and flowers on growth characteristics by growth period of winter-planted and summercultivated paprika 'Redwing RZ'.

\begin{tabular}{|c|c|c|c|c|c|c|}
\hline $\begin{array}{l}\text { Growth } \\
\text { Period }\end{array}$ & Treatment & $\begin{array}{c}\text { Plant Growth } \\
\text { Speed }^{\mathrm{z}} \\
(\mathrm{cm} / \text { Week })\end{array}$ & $\begin{array}{l}\text { Flower } \\
\text { Position } \\
(\mathrm{cm})\end{array}$ & $\begin{array}{c}\text { Stem } \\
\text { Diameter } \\
(\mathrm{mm})\end{array}$ & $\begin{array}{l}\text { Node Growth } \\
\text { Speed }{ }^{y} \\
\text { (Node/Week) }\end{array}$ & No. of Leaves \\
\hline \multirow{5}{*}{1} & F1L2 & $8.22 \mathrm{ab}^{\mathrm{x}}$ & $4.62 \mathrm{~b}$ & $5.5 \mathrm{a}$ & $1.18 \mathrm{a}$ & $2.35 \mathrm{c}$ \\
\hline & F2L2 & $7.93 \mathrm{~b}$ & $4.81 \mathrm{~b}$ & $5.5 \mathrm{a}$ & $1.15 \mathrm{a}$ & $2.30 \mathrm{c}$ \\
\hline & F2L3 & $8.14 \mathrm{ab}$ & $4.84 \mathrm{~b}$ & $5.5 \mathrm{a}$ & $1.20 \mathrm{a}$ & $3.57 \mathrm{~b}$ \\
\hline & F2L4 & $8.56 \mathrm{a}$ & $5.44 \mathrm{a}$ & $5.4 \mathrm{a}$ & $1.20 \mathrm{a}$ & $4.79 \mathrm{a}$ \\
\hline & Average & 8.22 & 4.93 & 5.5 & 1.18 & 3.27 \\
\hline \multirow{5}{*}{2} & F1L2 & $7.87 \mathrm{ab}$ & $4.16 \mathrm{a}$ & $5.7 \mathrm{a}$ & $1.22 \mathrm{a}$ & $2.44 \mathrm{c}$ \\
\hline & F2L2 & $8.27 \mathrm{a}$ & $4.13 \mathrm{a}$ & $5.4 \mathrm{~b}$ & $1.21 \mathrm{a}$ & $2.43 c$ \\
\hline & F2L3 & $7.70 \mathrm{~b}$ & $3.71 \mathrm{~b}$ & $5.2 \mathrm{~b}$ & $1.15 \mathrm{a}$ & $3.45 \mathrm{~b}$ \\
\hline & F2L4 & $8.06 \mathrm{ab}$ & $4.43 \mathrm{a}$ & $5.3 \mathrm{~b}$ & $1.25 \mathrm{a}$ & $5.02 \mathrm{a}$ \\
\hline & Average & 7.98 & 4.11 & 5.4 & 1.21 & 3.35 \\
\hline \multirow{5}{*}{3} & F1L2 & $9.23 \mathrm{~b}$ & $4.78 \mathrm{~b}$ & $5.9 \mathrm{a}$ & $1.36 \mathrm{a}$ & $2.72 \mathrm{c}$ \\
\hline & F2L2 & $9.85 \mathrm{a}$ & $4.46 \mathrm{c}$ & $5.7 \mathrm{ab}$ & $1.07 \mathrm{~b}$ & $2.14 \mathrm{~d}$ \\
\hline & F2L3 & $9.48 \mathrm{ab}$ & $4.21 \mathrm{c}$ & $5.5 \mathrm{c}$ & $1.06 \mathrm{~b}$ & $3.19 \mathrm{~b}$ \\
\hline & F2L4 & $9.92 \mathrm{a}$ & $5.53 \mathrm{a}$ & $5.6 \mathrm{bc}$ & $1.35 \mathrm{a}$ & $5.40 \mathrm{a}$ \\
\hline & Average & 9.62 & 4.75 & 5.7 & 1.21 & 3.38 \\
\hline \multirow{5}{*}{4} & F1L2 & $6.83 \mathrm{ab}$ & $3.77 \mathrm{~b}$ & $5.1 \mathrm{a}$ & $1.16 \mathrm{a}$ & $2.32 \mathrm{c}$ \\
\hline & F2L2 & $6.49 \mathrm{~b}$ & $3.57 \mathrm{~b}$ & $5.1 \mathrm{ab}$ & $1.12 \mathrm{a}$ & $2.25 \mathrm{c}$ \\
\hline & F2L3 & $6.81 \mathrm{ab}$ & $3.86 \mathrm{ab}$ & $5.1 \mathrm{a}$ & $1.10 \mathrm{a}$ & $3.32 \mathrm{~b}$ \\
\hline & F2L4 & $7.43 \mathrm{a}$ & $4.31 \mathrm{a}$ & $4.8 \mathrm{~b}$ & $1.22 \mathrm{a}$ & $4.87 \mathrm{a}$ \\
\hline & Average & 6.87 & 3.86 & 5.1 & 1.15 & 3.14 \\
\hline \multirow{5}{*}{5} & F1L2 & $5.79 \mathrm{a}$ & $3.25 \mathrm{a}$ & $4.4 \mathrm{a}$ & $1.05 \mathrm{a}$ & $2.10 \mathrm{c}$ \\
\hline & F2L2 & $4.74 \mathrm{~b}$ & $2.38 \mathrm{~b}$ & $4.0 \mathrm{~b}$ & $0.97 \mathrm{a}$ & $1.93 \mathrm{c}$ \\
\hline & F2L3 & $4.98 \mathrm{ab}$ & $2.47 \mathrm{~b}$ & $3.9 \mathrm{~b}$ & $1.03 \mathrm{a}$ & $3.09 \mathrm{~b}$ \\
\hline & F2L4 & $5.64 \mathrm{a}$ & $2.55 \mathrm{~b}$ & $3.9 \mathrm{~b}$ & $1.06 \mathrm{a}$ & $4.25 \mathrm{a}$ \\
\hline & Average & 5.21 & 2.61 & 4.1 & 1.02 & 2.84 \\
\hline \multicolumn{2}{|c|}{ Significance $\mathrm{w}$} & & & & & \\
\hline \multicolumn{2}{|c|}{ Period (A) } & $* * *$ & $* * *$ & $* * *$ & $* * *$ & $* * *$ \\
\hline \multicolumn{2}{|c|}{ Treatment (B) } & $* *$ & $* *$ & $* * *$ & $* * *$ & $* * *$ \\
\hline \multicolumn{2}{|c|}{$A \times B$} & * & NS & $*$ & $* * *$ & $* * *$ \\
\hline
\end{tabular}

${ }^{\mathrm{z}}$ Plant growth speed (cm/week): plant height in this week—plant height in last week. ${ }^{\mathrm{y}}$ Node growth speed (node/week): number of nodes in this week-number of nodes in last week. ${ }^{\times}$Differences in the mean separation within the columns by Duncan's multiple range test $(p=0.05)$ are indicated by lowercase letters. ${ }^{\mathrm{w}} \mathrm{NS}$, not significant; significant at $p<0.1 ;{ }^{*}, p<0.05 ;{ }^{* *}, p<0.01 ;{ }^{* * *}, p<0.001$.

In the case of the flowering position, it was shown to have a vegetative growth type in which the flowering position became higher as the number of leaves increased. This was because it had developed into a vegetative growth type due to favorable plant thermoregulation and the high sink strength of the growing point due to a high LAI. However, in Period 5, the cumulative LAI was high in F2L4. However, as can be seen from the decreased LAI in the upper part and the cumulative LAI graph (Figure 1), we confirmed that the advantage of thermoregulation disappeared and the flowering position was lowered because the energy loss was greater than the advantage of increasing the number of leaves due to insufficient photosynthesis caused by a low light. In addition, in Periods 2 and 3, F2L3 showed the lowest flowering position values, although they were intermediate values. This was not because the flowering rate was accelerated due to environmental causes. Although the fruit setting number was less in F2L3 than in F2L4, 
the large difference in the average fruit weight caused distribution of assimilates to move to fruits, resulting in a shortened flowering position due to a poor growth.

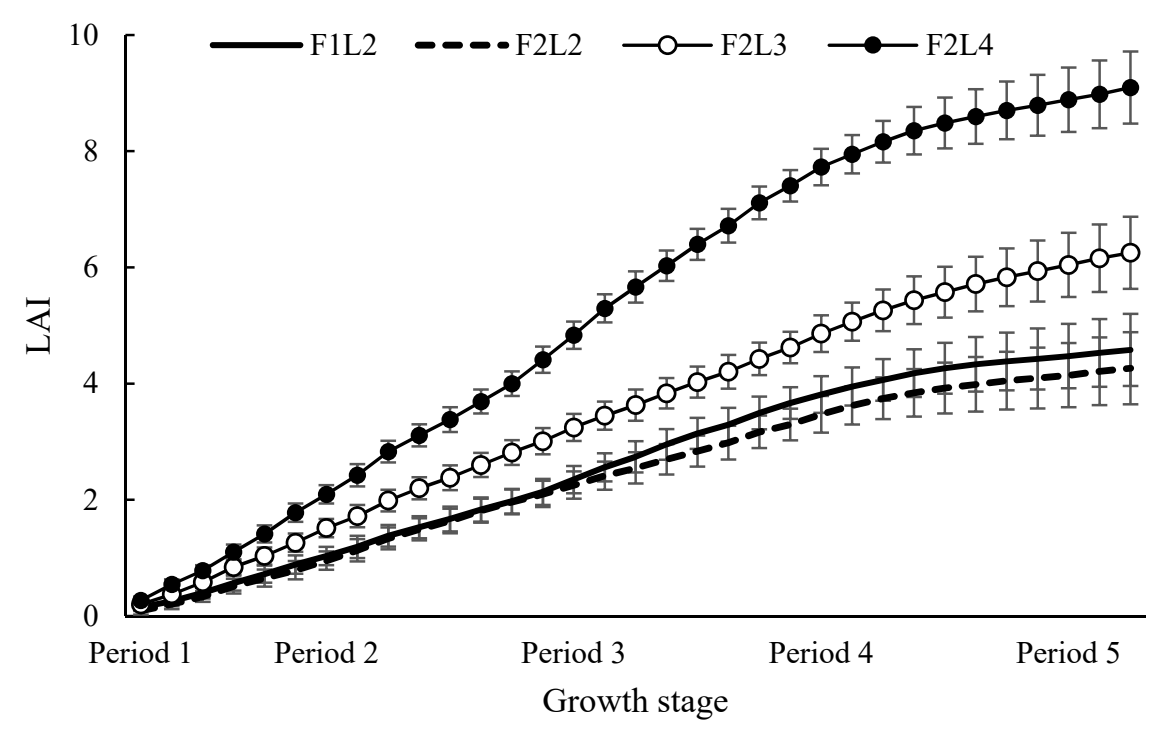

Figure 1. Accumulate LAI.

Regarding the flowering position, in all periods, the larger the number of leaves, the higher the flowering position due to an increase in LAI, resulting in vegetative growth development. However, in Period 2, F2L3 had the lowest flowering position despite its high number of leaves. This finding was thought to be due to the fact that more assimilates moved to the sink organ than in other treatment plots due to an increase in the highest average fruit weight. As a result, the plant strength was weakened and the position of flowering was lower.

In contrast to results of thinning of the stem diameter with increasing LAI [12], the difference in the stem diameter caused by the number of leaves in this experiment was not statistically significant. However, a slight difference was observed, depending on the fruit setting number. This might be because the sink strength that went to the main stem was the same. The difference in the stem diameter was due to the difference in sink strength that went to the fruit. This was why the volume growth in Periods 2 and 3, in which the amount of light increased, showed a big difference. Although the rate of node development did not show significant differences in values among treatment plots, growth rates of F2L2 and F2L3 were about $28 \%$ slower than those of F1L2 and F2L4 only in Period 3. This suggested that the treatment plot with the lowest fruit setting number and the treatment with the highest fruit setting number reacted sensitively to the growth rate as the 24-h average temperature increased.

As a result of investigating fruit setting characteristics of paprika after planting by adjusting the sink and source (Table 2), in the treatment plot that controlled the number of leaves and adjusted the fruit setting number, the result was analyzed according to the treatment for the experiment. In the treatment plot that controlled the fruit setting number and adjusted the number of leaves, the higher the number of leaves, the higher the fruit setting number. 
Table 2. Effects of side leaves and flowers on fruit characteristics by growth period of winter-planted and summer-cultivated paprika 'Redwing RZ'.

\begin{tabular}{|c|c|c|c|c|c|c|}
\hline $\begin{array}{l}\text { Growth } \\
\text { Period }\end{array}$ & $\begin{array}{l}\text { No. of } \\
\text { Fruits }\end{array}$ & $\begin{array}{l}\text { No. of } \\
\text { Leaves }\end{array}$ & $\begin{array}{c}\text { No. of } \\
\text { Fruit Sets }\end{array}$ & $\begin{array}{c}\text { No. of } \\
\text { Harvested } \\
\text { Fruits }\end{array}$ & $\begin{array}{c}\text { Ratio of } \\
\text { Harvested }^{\mathrm{z}} \\
\text { (\%) }\end{array}$ & $\begin{array}{c}\text { Average } \\
\text { Fruit Weight } \\
\text { (g) }\end{array}$ \\
\hline \multirow{5}{*}{1} & 1 & 2 & $3.54 b^{y}$ & $1.44 \mathrm{a}$ & $41 \mathrm{a}$ & $266.6 \mathrm{~b}$ \\
\hline & 2 & 2 & $3.84 \mathrm{~b}$ & $1.35 \mathrm{a}$ & $35 \mathrm{a}$ & $260.6 \mathrm{~b}$ \\
\hline & 2 & 3 & $3.79 \mathrm{~b}$ & $1.26 \mathrm{a}$ & $33 a$ & $271.8 \mathrm{a}$ \\
\hline & 2 & 4 & $4.33 \mathrm{a}$ & $1.44 \mathrm{a}$ & $33 a$ & $255.4 \mathrm{c}$ \\
\hline & \multicolumn{2}{|c|}{ Average } & 3.88 & 1.37 & 36 & 263.6 \\
\hline \multirow{5}{*}{2} & 1 & 2 & $3.75 \mathrm{~b}$ & $1.89 \mathrm{a}$ & $50 a$ & $250.6 \mathrm{a}$ \\
\hline & 2 & 2 & $3.98 \mathrm{~b}$ & $1.68 \mathrm{a}$ & $42 \mathrm{a}$ & $239.9 \mathrm{~b}$ \\
\hline & 2 & 3 & $4.08 \mathrm{~b}$ & $1.62 \mathrm{a}$ & $40 \mathrm{a}$ & $240.1 \mathrm{~b}$ \\
\hline & 2 & 4 & $4.46 \mathrm{a}$ & $1.95 \mathrm{a}$ & $44 \mathrm{a}$ & $223.4 \mathrm{c}$ \\
\hline & \multicolumn{2}{|c|}{ Average } & 4.07 & 1.79 & 44 & 238.6 \\
\hline \multirow{5}{*}{3} & 1 & 2 & $3.25 \mathrm{a}$ & $1.26 \mathrm{a}$ & $39 a$ & $216.8 \mathrm{ab}$ \\
\hline & 2 & 2 & $3.63 \mathrm{a}$ & $1.56 \mathrm{a}$ & $43 a$ & $220.8 \mathrm{a}$ \\
\hline & 2 & 3 & $3.61 \mathrm{a}$ & $1.44 \mathrm{a}$ & $40 \mathrm{a}$ & $208.7 b$ \\
\hline & 2 & 4 & $3.56 \mathrm{a}$ & $1.41 \mathrm{a}$ & $40 \mathrm{a}$ & $210.4 \mathrm{~b}$ \\
\hline & \multicolumn{2}{|c|}{ Average } & 3.52 & 1.42 & 40 & 214.2 \\
\hline \multirow{5}{*}{4} & 1 & 2 & $4.04 \mathrm{~b}$ & $1.21 \mathrm{a}$ & $30 a$ & $216.2 \mathrm{a}$ \\
\hline & 2 & 2 & $5.42 \mathrm{a}$ & $1.29 \mathrm{a}$ & $24 \mathrm{a}$ & $184.6 \mathrm{c}$ \\
\hline & 2 & 3 & $4.79 \mathrm{a}$ & $1.74 \mathrm{a}$ & $36 a$ & $194.4 \mathrm{~b}$ \\
\hline & 2 & 4 & $5.10 \mathrm{a}$ & $1.35 \mathrm{a}$ & $26 a$ & $189.7 \mathrm{bc}$ \\
\hline & \multicolumn{2}{|c|}{ Average } & 4.84 & 1.40 & 29 & 196.3 \\
\hline \multirow{5}{*}{5} & 1 & 2 & $3.25 \mathrm{~b}$ & $1.74 \mathrm{a}$ & $54 \mathrm{a}$ & $186.3 \mathrm{a}$ \\
\hline & 2 & 2 & $3.72 \mathrm{~b}$ & $3.09 \mathrm{a}$ & $83 \mathrm{a}$ & $156.4 \mathrm{c}$ \\
\hline & 2 & 3 & $3.87 \mathrm{~b}$ & $2.07 \mathrm{a}$ & $53 a$ & $176.7 \mathrm{~b}$ \\
\hline & 2 & 4 & $4.81 \mathrm{a}$ & $2.82 \mathrm{a}$ & $59 a$ & 183.3 a \\
\hline & \multicolumn{2}{|c|}{ Average } & 3.92 & 2.43 & 62 & 175.7 \\
\hline \multicolumn{7}{|c|}{ Significance $^{\mathrm{x}}$} \\
\hline \multicolumn{3}{|c|}{ Period (A) } & $* * *$ & $* * *$ & $* * *$ & $* * *$ \\
\hline \multicolumn{3}{|c|}{ Age (B) } & $* * *$ & NS & NS & $* * *$ \\
\hline \multicolumn{3}{|c|}{$\mathrm{A} \times \mathrm{B}$} & $* *$ & NS & NS & NS \\
\hline
\end{tabular}

${ }^{\mathrm{z}}$ Ratio of harvested (\%): number of harvested fruits/number of fruit sets. ${ }^{\mathrm{y}}$ Differences in the mean separation within the column by Duncan's multiple range test $(p=0.05)$ are indicated by lowercase letters. ${ }^{\times}$NS, not significant; significant at $p<0.1 ;{ }^{*}, p<0.05 ;{ }^{* *}, p<0.01$; $* * *, p<0.001$.

However, in Period 3, the difference was not statistically significant, which was likely due to the effect of excessive respiratory volume caused by an increase in the 24-h average temperature (Figure 2).

Too high a temperature also affected the distribution of assimilates to nutritional and reproductive organs by adjusting the respiratory volume in response to temperature conditions.

As for the number of harvested paprikas, in Periods 1 and 2, in the early stage of growth, the number of fruit harvested increased slightly as the fruit setting number under the same leaf number condition decreased. In Periods 3, 4, and 5, the late stage of growth, the number of harvested fruits increased as the fruit setting number increased. 


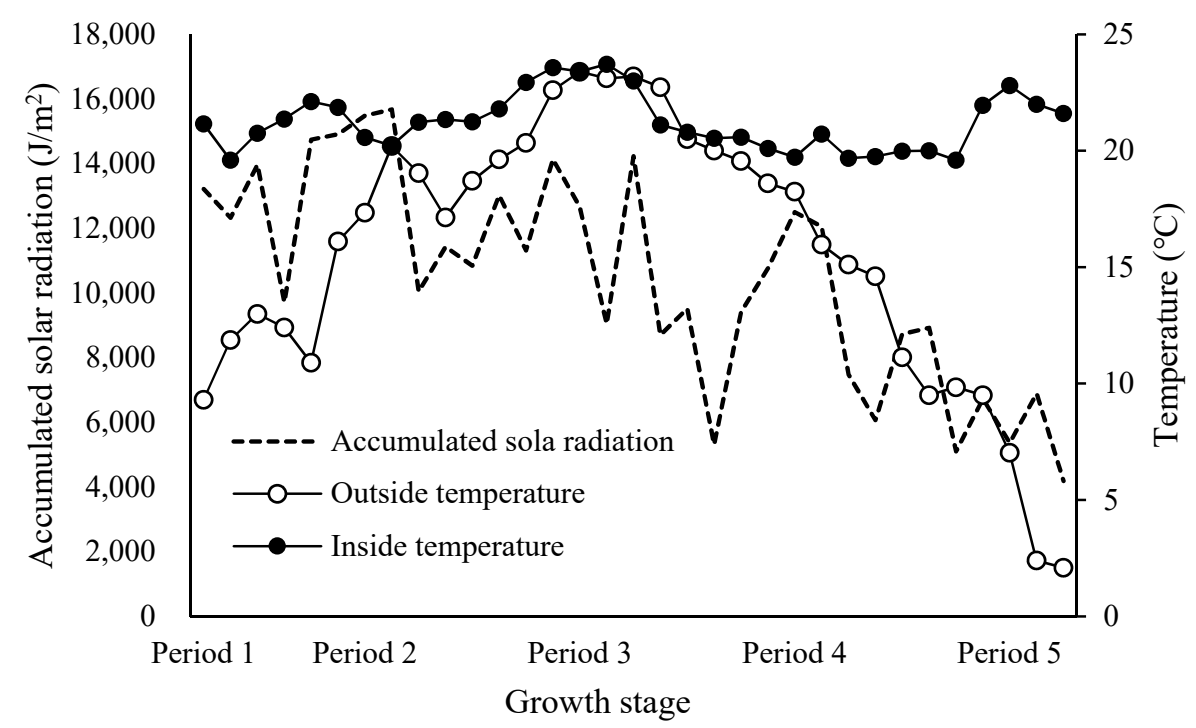

Figure 2. Weekly integrated accumulated solar radiation, 24-h average air temperature outside the greenhouse, and 24-h average air temperature inside the greenhouse.

In particular, in Period 5, F1L2 and F2L2 showed about 77\% difference. This was probably most affected by the cutting treatment at the end of growth when the fruit setting number of F1L2 was set to be small. The average fruit weight increased as the fruit setting number decreased under the condition of the same number of leaves except for Period 3. In particular, the difference was significant in Periods 4 and 5, which was consistent with a report that an increase in the number of harvested fruit reduced the average fruit weight [7]. In Period 3, it was determined that the growth balance decreased due to an increase in the 24-h average outside temperature. In addition, the average fruit weight of F2L2 was higher than that of F1L2 due to the stem diameter being thicker and the increased growth rate of F1L2. In treatment plots with the same fruit setting number, characteristics of average fruit weight of each treatment for Periods 1,2, and 6 showed significant differences in the fruit setting number. In Periods 1 and 2, F2L4 had the lowest average fruit weight due to the highest fruit setting number. In Period 5, F2L4 had the highest fruit setting number. Its average fruit weight was also the highest. In Periods 1 and 2, the distribution rate of assimilates decreased due to increases in sink organs. In Period 5, light transmittance under the same conditions was formed in all treatment plots in a situation where the increase in the number of leaves was limited after cutting. These results were judged to be due to the transfer of sufficient assimilates to the last fruit set in the F2L4 treatment plot that secured the most number of leaves. This is because the amount of photosynthesis of a crop is determined not only by the LAI, but also by the light transmittance of the crop [13]. In addition, movement of sugar to source organs depends on the distance from the sink organ.

As a result of the relative comparison of plant height according to the LAI of each treatment plot to examine the complex relationship between growth indicators (Figure 3), when the number of leaves was the same, the LAI was slightly higher in the treatment plot with a small fruit setting number, although such a difference was not statistically significant. However, when the number of leaves was set as the same and the number of leaves was adjusted, the higher the number of leaves, the higher the LAI. The resulting overall plant height showed similar values, although F1L2 and F2L4 showed the highest values. This was considered to be due to the fact that, in the treatment plot with a small fruit setting number, assimilates consumed by the fruit were less. Thus, the more the number of leaves, the more it was biased toward a vegetative growth [10]. These results are thought to be due to that fact that a low crop load will decrease fruit sink strength, leading to extra accumulation of non-structural carbohydrates in source leaves [14]. 


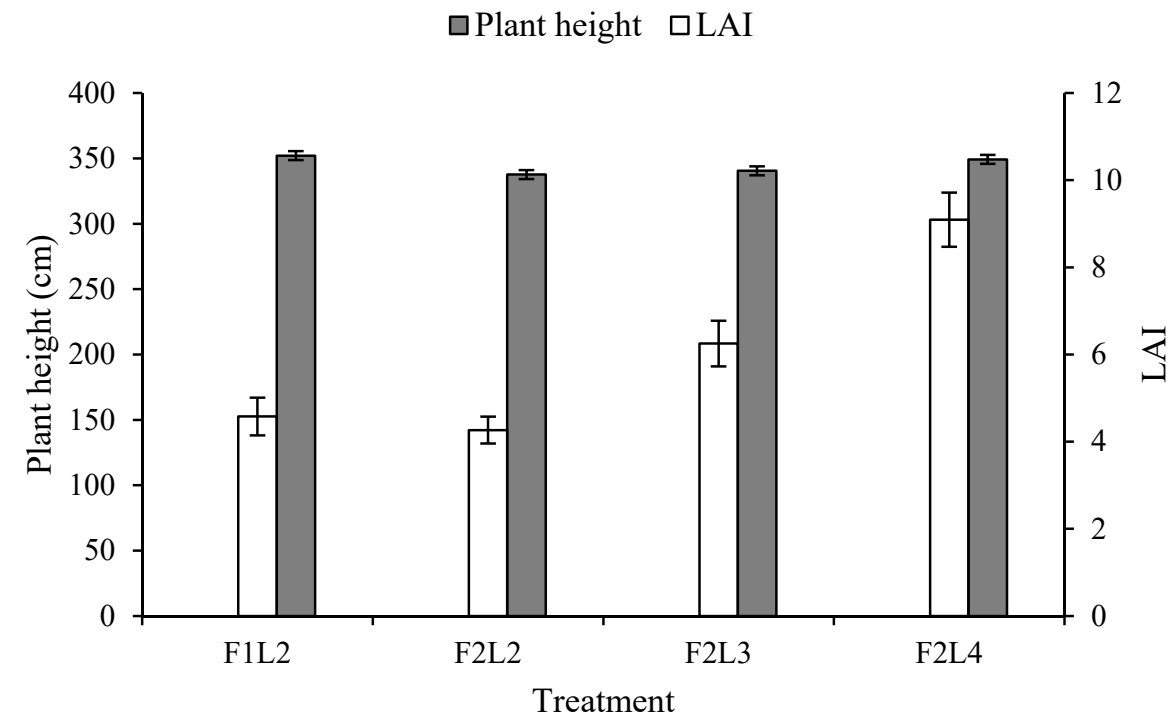

Figure 3. Effects of lateral leaves and flowers on plant height and LAI by growth period in winterplanted and summer-cultivated paprika 'Redwing RZ'. Plant height was calculated as the length from the root to the shoot tip (left). The leaf area index (LAI) was calculated as leaf length $(\mathrm{cm}) \times$ leaf width $(\mathrm{cm}) \times 0.6 \times$ stem density $\left(\right.$ stem $\left./ \mathrm{m}^{2}\right) \times$ number of leaves on the main stem + (number of leaves on the lateral stems $\times 0.7)\}$ (right). Error bars indicate the standard deviation of sample means $(n=144)$.

Cumulative yield is shown in Figure 4. It clearly shows the distribution of assimilates to sink organs. The cumulative yield increased in F2L2 where the number of leaves increased in F1L2 and F2L2 under the same conditions.

This finding might have been due to the distribution of assimilates caused by the difference in fruit setting number because a sink organ directly affects the yield. This suggested that the difference in the fruit setting number directly affected the production volume.

However, in Period 2, F1L2 showed a higher yield than F2L2, although the growth length in Period 2 was longer in F2L2 than that in F1L2. The growth balance was relatively broken in F2L2 compared to that in F1L2 due to underdeveloped stem diameter, which was considered to be the effect of difference in the average fruit weight that was significantly different, not due to the difference in the fruit setting number that was not significantly different. When each fruit setting number was the same, the initial yield was benefitted by removing the number of leaves during early stages of growth. The reduction in yield may have been due to the growth imbalance caused by the removal of the lateral branches at the late stage of growth [15]. As for the initial yield, it was found that F2L2 and F2L3 showed better yields than F2L4. F2L4 showed a higher yield than F2L2 and F2L3 in late stages of growth. In the case of the total yield, similar to the result that proper leaf removal could increase the yield [1], the yield was the highest in the F2L3 treatment group where the number of leaves had an intermediate value. In the case of total production, the highest production was seen in the F2L3 treatment plot, similar to a previous study showing that proper removal of the number of leaves could increase production [1].

Considering this, findings of this study can be used as basic data in practical terms when making decisions on the number of leaves and fruit setting number at farms in the highlands of South Korea where the area of paprika cultivation is continuously increasing. 


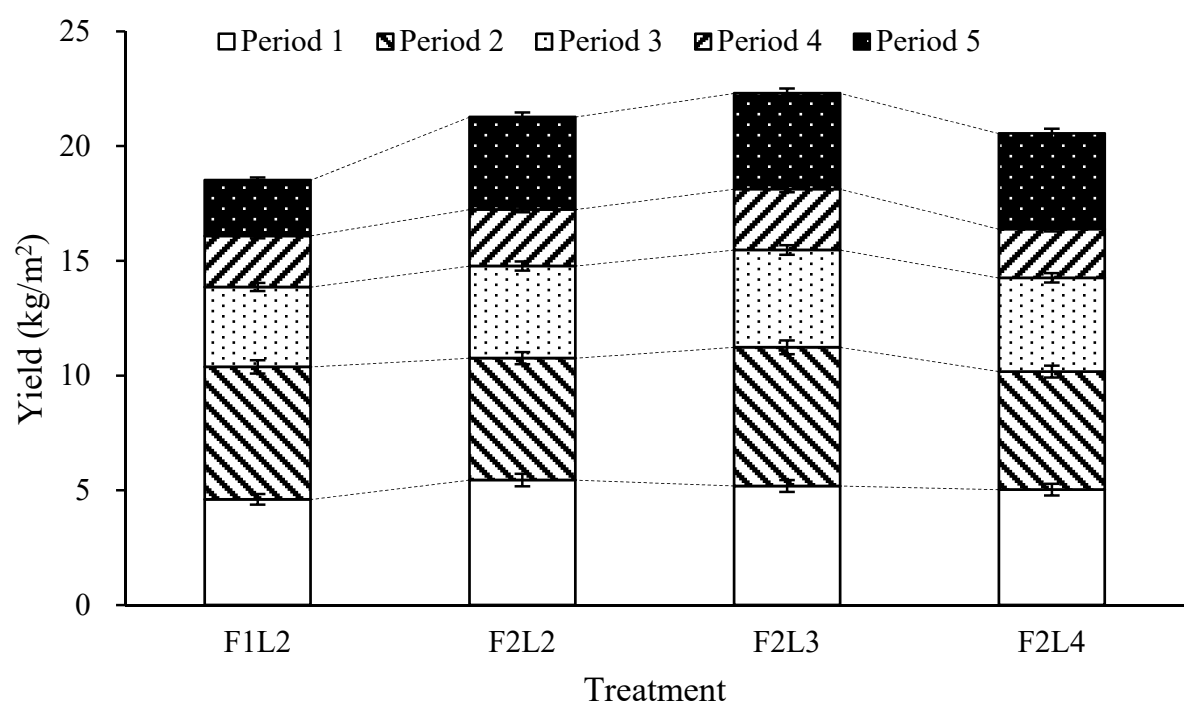

Figure 4. Effects of lateral leaves and flowers on yield by growth period in winter-planted and summer-cultivated paprika 'Redwing RZ'. Each growth period was divided into 8 weeks after treatment. Error bars indicate the standard deviation of sample means $(n=144)$.

Previous studies on the regulation of the number of leaves and fruit setting number of paprika were conducted within a standardized range of planting in summer and harvesting in winter and two-stem cultivation. In contrast, this study was differentiated from previous studies in that it was a newly emerging cultivation type, a method of planting in winter and harvesting in summer and three-stem cultivation, and $\mathrm{CO}_{2}$ was sufficiently supplied even in summer when the ventilation requirements were high.

It was expected that the higher the number of sink organs, the slower the growth development, or the fewer the number of sink organs, the higher the average fruit weight. Although there were similar cases, according to the amount of light and the 24-h average temperature condition, it was confirmed that the growth development was good and the average weight increased even though there were many sink organs. It was confirmed that the development of the source organ was not unilaterally biased toward a vegetative growth and a reproductive growth in each treatment plot, but changed according to the amount of light and the 24-h average temperature condition.

\section{Conclusions}

As a result of this experiment, it is appropriate to keep two leaves in the early stage of growth. As the amount of light becomes stronger, it is necessary to increase the number of leaves to three. Contrary to the expectation that a large number of leaves would decrease production during the high-temperature period, the production increased as the number of leaves increased. However, since the average fruit weight showed a tendency to decrease, it was judged that lowering the number of leaves and fruits during the high-temperature period could improve profitability. It is recommended to maintain up to four leaves in the late-growth period when the plant strength of paprika is weakened. In conclusion, it was confirmed that, in the case of long-term cultivation of paprika, the use of branched fruit and the maintenance of two or more branches depending on the season are more helpful in improving the yield than the conventional cultivation method. This result is expected to help improve the profitability of paprika growers.

Author Contributions: Conceptualization, D.-C.J. and S.-H.Y.; methodology, W.-H.N.; validation, D.-C.J., S.-H.Y. and W.-H.N.; formal analysis, M.-H.J.; investigation, H.-C.Y.; resources, M.-H.J., Y.-H.K. and E.-H.H.; writing — original draft preparation, D.-C.J.; writing—review and editing, K.-Y.C.; visualization, D.-C.J. and N.-T.V.; supervision, I.-S.K.; project administration, K.-Y.C. and 
N.-T.V.; funding acquisition, I.-S.K. All authors have read and agreed to the published version of the manuscript.

Funding: This research received fund by Korea Institute of Planning and Evaluation for Technology in Food, Agriculture and Forestry (IPET) through (Smart Farm Innovation Technology Development Program), funded by The Ministry of Agriculture, Food and Rural Affairs (MAFRA) (421040-04).

Institutional Review Board Statement: Not applicable.

Informed Consent Statement: Not applicable.

Data Availability Statement: Data are available in a publicly accessible repository.

Acknowledgments: This work was supported by Korea Institute of Planning and Evaluation for Technology in Food, Agriculture and Forestry (IPET) through (Smart Farm Innovation Technology Development Program), funded by The Ministry of Agriculture, Food and Rural Affairs (MAFRA) (421040-04).

Conflicts of Interest: The authors declare no conflict of interest.

\section{References}

1. Kim, S.E.; Lee, M.Y.; Kim, Y.S. Optimum management of tomato leaf removal in summer. J. Agric. Life Sci. 2013, $47,11-17$.

2. Hussey, G. Growth and development in the young tomato: II. The effect of defoliation on the development of the shoot apex. J. Expt. Bot. 1963, 1, 326-333. [CrossRef]

3. Aung, L.H. Influences of certain plant factors on the growth and fruiting of the lower axillary shoot of Lycopersicon esculentum Mill. Ann. Bot. 1976, 40, 723-729. [CrossRef]

4. Buchanan-Wollaston, V. The molecular biology of leaf senescence. J. Expt. Bot. 1997, 48, 181-199. [CrossRef]

5. Worku, M.; Banziger, M.; Erley, G.S.; Friesen, D.; Diallo, A.O.; Horst, W.J. Nitrogen uptake and utilization in contrasting nitrogen efficient tropical maize hydrids. Crop. Sci. 2007, 47, 519-528. [CrossRef]

6. Lee, S.W.; Hwang, G.C.; Yun, J.G.; Hong, J.K.; Park, S.J. Effect of various fruit-loads on yield, fruit quality and growth of 'Seolhyang' strawberry. Prot. Hortic. Plant Fact. 2014, 3, 205-211. [CrossRef]

7. Webb, R.A. A possible influence of pedicel dimensions on fruit size and yield in strawberry. Sci. Horic. 1973, 1, 321-330. [CrossRef]

8. Dorais, M.; Yelle, S.; Gosselin, A. Influence of extended photoperiod on photosynthate partitioning and export in tomato and pepper plants. N. Z. J. Crop Hortic. Sci. 1996, 24, 29-37. [CrossRef]

9. Hao, X.; Hale, B.A.; Ormrod, D.P. The effects of ultraviolet-B radiation and carbon dioxide on growth and photosynthesis of tomato. Can. J. Bot. 1997, 75, 213-219. [CrossRef]

10. Lee, J.H.; Cha, J.C. Effects of removed flowers on dry mass production and photosynthetic efficiency of sweet pepper cultivars 'Derby' and 'Cupra'. Korean J. Hortic. Sci. Technol. 2009, 27, 584-590.

11. Marcelis, L.F.M.; Heuvelink, E.; Hofman-Eijer, L.R.B.; Bakker, J.D.; Xue, L.B. Flower and fruit abortion in sweet pepper in relation to source and sink strength. J. Expt. Bot. 2004, 55, 2261-2268. [CrossRef] [PubMed]

12. Carl, E.M. In-row plant spacing affects growth and yield of pepperoncini pepper. Hort. Sci. 1996, 31, 198-200. [CrossRef]

13. Geelen, P.A.M.; Voogt, J.O.; van Weel, P.A.M. Plant Empowerment the Basic Principles; Letsgrow: Vlaardingen, The Netherlands, 2018.

14. Yang, X.; Chen, L.S.; Cheng, L. Leaf photosynthesis and carbon metabolism adapt to crop load in 'Gala' Apple trees. Horticulture. 2021, 7, 47. [CrossRef]

15. Kim, S.E.; Lee, J.E.; Sim, S.Y.; Lee, M.H.; Kim, Y.S. Optimum management of tomato side shoot removal in winter. Prot. Hortic. Plant Factor 2014, 23, 309-313. [CrossRef] 